DOI: https://doi.org/10.36910/6775-2524-0560-2021-43-33

УДК 004.89

Мельник Катерина Вікторівна, к.т.н., доцент,

http://orcid.org/0000-0002-9991-582X

Мельник Василь Михайлович, к.ф.-м.н., доцент,

http://orcid.org/0000-0001-8282-6639

Нестерук Віктор Олександрович, магістрант

Луцький національний технічний університет

\title{
МЕТОДИ МАШИННОГО НАВЧАННЯ У ТРЕНУВАННІ ІГРОВОГО ШТУЧНОГО ІНТЕЛЕКТУ НА ПРИКЛАДІ АГЕНТА У ГРІ SNАКЕ
}

\begin{abstract}
Мельник К. В., Мельник В. М., Нестерук В. О. Методи машинного навчання у тренуванні ігрового штучного інтелекту на прикладі агента у грі Snake. У даній статті розглянуто низку концепцій, що використовуються в ігровому штучному інтелекті (скорочено "ігровий ШІ"). У цій роботі наведено методи, доступні для вирішення проблем у галузі ігрового ШІ. Розглянуто проблеми ігрового ШІ у широкому розумінні, що включає все, від простих закодованих шаблонів, до нейронних мереж та генетичних алгоритмів.

Ключові слова: ігровий штучний інтелект, алгоритми машинного навчання, гра Snake.
\end{abstract}

Мельник К. В., Мельник В.М., Нестерук В. А. Методы машинного обучения в тренировке игрового искусственного интеллекта на примере агента в игре Snake. В данной статье рассмотрен ряд концепций, используемых в игровом искусственном интеллекте (сокращенно "игровой ИИ"). В этой работе приведены методы, доступные для решения проблем в области игрового ИИ. Рассмотрено проблемы игрового ИИ в широком смысле, включающий все, от простых закодированных шаблонов, к нейронным сетем и генетическим алгоритмам.

Ключевые слова: игровой искусственный интеллект, алгоритмы машинного обучения, игра Snake.

Melnyk K., Melnyk V., Nesteruk V. Methods of machine learning in the training of game artificial intelligence on the example of an agent in the game Snake. This article discusses a number of concepts used in gaming artificial intelligence (shortened "game AI"). This paper presents methods available for solving problems in the field of game AI. We looked at the problems of game AI in a wide sense, which includes everything from simple coded patterns to neural networks and genetic algorithms.

Keywords: game artificial intelligence, machine learning algorithms, Snake game.

Вступ. Ігри $є$ хорошим майданчиком для дослідження та використання штучного інтелекту(ШІ). Необхідність ШІ вирішувати складні проблеми з прийняття рішень в іграх дозволяє вивчити більшість його аспектів. Часто, ігровий ШІ зводиться до створення агентів ШІ, які $\epsilon$ конкурентоспроможними для людини, проте, існують і інші цікаві аспекти у цьому напрямку, такі як, використання ШІ для проектування нових ігор та наповнення ігрового вмісту. Розглянуто однин із напрямків створення ігрового штучного інтелекту.

Сучасні здобутки у сфері ігрового ШІ продемонстрували, що, за наявності у машини достатніх даних із людського досвіду, отриманого в результаті навчання, вона може як конкурувати як із звичайними людьми-гравцями, так і перевершувати найбільш вправних гравців у іграх будь якої складності. Проте, кожен з таких ШІ є достатньо обмеженим та вузько направленим, крім того, вони часто вимагають значних обчислювальних потужностей, не є схильними до значних змін в силу непрозорості у прийнятті рішень. Тому актуальною $є$ проблема створення більш універсальних ШІ, адаптивних та швидких у моделюванні, більш надійних та прозорих.

Поняття ігрового штучного інтелекту

Переважно, завданням ігрового ШІ є вибір дії, або дій, зважаючи на умови, в яких він знаходиться. Традиційна література $з$ штучного інтелекту називає це керуванням "інтелектуальними агентами". Таким агентом може бути будь який об'єкт: персонаж гри, машина, робот, або навіть щось більш абстрактне - ціла група об'єктів, країна або цивілізація. У будь-якому випадку це сутність, що стежить за своїм оточенням, що приймає на підставі нього рішення і діє відповідно до цих рішень. У тій же літературі це можна зустріти під назвою цикл «сприйняття-мислення-дія».

- Сприйняття: агент отримує та розпізнає інформацію про оточення, яка впливає, або може вплинути, на його стан (наприклад, чи поблизу небезпека, або необхідні до збору предмети, важливі місця).

- Мислення: агент обирає стратегію подальших дій у відповідь на подію (наприклад, чи безпечно зібрати необхідні предмети, чи варто йому контактувати з іншим об'єктом, чи ігнорувати)

- Дія: агент виконує відповідно обраній стратегії (наприклад, починає рухатися за маршрутом до предмету, чи іншого об’єкту) 
- Далі, відповідно до дій персонажів ситуація змінюється, агент отримує нові дані та цикл повторюється.

Особливо актуальні сьогодні розробки ШІ у реальному часі, які переважно зосереджені на завданнях «сприйняття» цього циклу. Наприклад, автопілот автомобіля отримує зображення дороги, яка знаходиться перед ним, поєднує ці дані з іншими (лідар-сенсору та радару) і інтерпретує отримане. Зазвичай такі завдання вирішуються алгоритмами машинного навчання, яке особливо добре працює 3 великими масивами даних реального світу (такими як, фотографії дороги перед автомобілем або декілька кадрів відео) і надає їм якесь значення, витягуючи важливу інформацію, наприклад «у 30-ти метрах попереду $є$ ще одне авто». Такі завдання відносять до завдань класифікації.

Ігри, у цьому плані, унікальні тим, що для вилучення такої інформації їм не потрібна складна система, оскільки вона є частиною симуляції. Немає необхідності виконувати алгоритми розпізнавання зображень, щоб виявити і класифікувати об'єкт перед собою; гра знає, що там знаходиться і може передати цю інформацію безпосередньо процесу прийняття рішень. Тому «сприйняття» агентів зазвичай дуже спрощено, а складність полягає у реалізації «мислення» та «дії».

\section{Обмеження у розробці ігрового ШІ}

Розробляючи ігровий ШІ потрібно мати на увазі такі обмеження:

- На відміну від алгоритмів машинного навчання, ігровий ШІ зазвичай не тренується заздалегідь;

- Зазвичай вважається, що гра повинна вміти як розважати, так і кидати гравцеві виклик, а не бути «оптимальною» - тому, навіть якщо можливо навчити агентів добре протистояти гравцям, то найчастіше це не єдине, що необхідно розробникам.

- Нерідко агентам висувають вимогу «реалістичної» поведінки, щоб гравці відчували, що змагаються з подібними їм супротивниками. Тому, алгоритм потрібно налаштувати таким чином, щоб він приймав правдоподібні рішення, а не ідеальні .

- ШІ повинен виконуватися «в реальному часі». Це означає, що алгоритм не може для прийняття рішення монополізувати ресурси процесора на тривалий час.

Прийнявши до уваги наведені пункти, розглянуто різні підходи до створення ШІ, які реалізують весь цикл «сприйняття-мислення-дія» способами, що забезпечують ефективність і дозволяють дизайнерам гри створювати складну поведінку, схожу на дії людини.

\section{Методи розробки ігрового ШІІ}

Як правило, методи ігрового ШІ мають два варіанти: детермінований та недетермінований.

Детермінована поведінка або дія є визначеною та передбачуваною. Прикладом детермінованої поведінки є простий алгоритм переслідування. Можна явно закодувати якийсь внутрішньо ігровий об’єкт для переміщення до якоїсь кінцевої точки, просуваючись уздовж осей координат X та Ү, поки координати $\mathrm{X}$ та Y об'єкту не співпадатимуть з кінцевим розташуванням.

Недетермінована поведінка $є$ протилежністю детермінованій. Така поведінка має ступінь невизначеності і $є$ дещо непередбачуваною (ступінь невизначеності залежить від алгоритму ШІ та того, наскільки добре навчений агент). Прикладом недетермінованої поведінки $\epsilon$ персонаж, який не $\epsilon$ гравцем, але який навчився пристосовуватися до тактики бою гравця. Таке навчання може використовувати нейронну мережу, байєсівський метод або генетичний алгоритм.

Детерміновані методи передбачувані, швидкі та прості у впровадженні, розумінні, тестуванні та налагодженні. Логічно, що такі методи мають передбачати багато різних сценаріїв поведінки, умов та станів ігрового ШІ, кодування яких у повному обсязі лягає на плечі розробникам. Крім того, детерміновані методи ніяк не сприяють навчанню та розвитку. Після нетривалого ігрового процесу така поведінка, як правило, стає передбачуваною, що в своєму розумінні, обмежує ігрове життя.

Недетерміновані методи у цьому плані полегшують навчання та роблять ігровий процес більш непередбачуваним. Розробники не повинні чітко кодувати всі способи поведінки у всеможливих сценаріях, оскільки недетерміновані методи зазвичай використовують нейромережі для свого ШІ, які самостійно, на прикладі вхідних даних, зможуть відповідно реагувати на оточення. Недетерміновані методи також можуть вчитися і розвиватись самостійно. Крім того, вони здатні до «екстреної» поведінки, тобто, можуть знайти рішення до ситуацій, у яких вони не перебували та не отримували будь яких вказівок щодо них.

Переважно розробники не люблять ШІ, який не є детермінованим. В силу непрозорості алгоритмів нейромереж, їх непередбачуваність складно перевірити та налагодити. До недавнього часу ще одним фактором, який обмежував розвиток ігрового ШІ, був той факт, що розробники зосереджували більшу частину своєї уваги на якості графіки. Як виявилось, такий фокус на розробці кращих і швидших графічних рішень, включаючи апаратне прискорення, тепер може дозволити виділити більше ресурсів 
на кращого, більш досконалого ШІ. Цей факт, поряд з тиском до створення наступної популярної гри, спонукає розробників ігор до більш ретельного вивчення недетермінованих методів.

В межах цієї статті розглянуто плюси і мінуси різних підходів з навчання ігрових агентів на базі гри Snake, де агент керує змійкою. В основному, до створення агента ШІ для Snake використовують підходи таких трьох категорій: підходи без машинного навчання, генетичні алгоритми та навчання 3 підкріпленням.

\section{Методи, що не стосуються машинного навчання}

Правила гри у Snake доволі прості: гравець керує змією, яка повинна маневрувати навколо екрану, поїдаючи яблука. 3 кожним з'їденим яблуком змія збільшує свій хвіст на одну одиницю. Мета цієї гри - з'їсти якомога більше яблук, не зачепивши стіну ігрового поля чи постійно зростаючий хвіст самої змії. Гра була розроблена на Руthon і спирається на фреймворк Рygame, одну з Руthon бібліотек, яка дозволяє досить легко розробляти прості ігри. Розмір поля становить $20 \times 20$, і в ньому присутнє лише одне яблуко, яке з'являється у новому випадковому вільному квадраті кожного разу, коли його буде з'їдено.

Гра Snake насправді має тривіальне, ідеальне рішення. Необхідно просто створити циклічний шлях, який ніде не перетинається та проходить через кожен квадрат на полі. Проте таке рішення суперечить вище наведеним обмеженням щодо розробки ігрового ШІ, оскільки не має ніякого сприйняття та не здатне прийняти будь які рішення, не імітує поведінку гравців і явно не здатне з ними конкурувати.

Тому, метод без машинного навчання було створено наступним чином. Після старту гри алгоритм керуватиме змією на полі, не виконуючи жодного процесу навчання. Алгоритм спочатку оцінює бали для кожного з чотирьох можливих напрямків руху змії (вправо, вліво, вгору, вниз), а потім обирає дію 3 найвищим значенням. Для того, щоб розрахувати ці бали, змія заздалегідь імітує рух на один крок вперед у кожному з напрямків і повертає рахунок на основі результату цього руху:

- мінус 1000 при зіткненні зі стіною або тілом змії;

- 1000 мінус відстань до найближчої їжі в іншому випадку.

Таким чином, рух, який викликає зіткнення, найймовірніше буде проігноровано, тоді як перевагу отримають такі дії, які зменшують відстань між головою змії та їжею.

Метод можна додатково вдосконалити, розширивши закодований алгоритм за допомогою динамічного алгоритму для того, щоб розрахувати оцінку кожної дії глибше. Проте, це суттєво уповільнило б швидкість гри.

Отже, резюмуємо даний метод.

Плюси: агент може гарантовано закінчити гру.

Мінуси: машинного навчання не задіяно - алгоритм повинен кодуватися вручну. Необхідні певні знання у теорії графів. Алгоритм може працювати повільно на великих ігрових полях.

\section{Генетичні алгоритми}

Генетичні алгоритми - ще один популярний підхід до такого типу проблем. На створення цього підходу надихнулись 3 біологічної еволюції та природного відбору. Такі алгоритми часто використовуються для створення високоякісних рішень для оптимізації та пошуку несправностей шляхом моделювання процесу природного відбору, а це означає, що лише ті види, які можуть пристосуватися до змін у своєму середовищі, здатні вижити, розмножитися та перейти до наступного покоління. Кожне покоління складається з сукупності індивідів, що в нашому випадку $є$ нейронними мережами, кожна з яких має свої ваги, отже кожна представляє різне рішення. Розглядаючи аналогію між генетичними алгоритмами та природним відбором, ми можемо порівняти ваги кожної людини 3 генетичною структурою хромосоми, яка мутує покоління за поколінням, щоб народити кращих особин. Модель машинного навчання відображає вплив входів на результати дій . Такими входами може бути відстань змії до перешкод у чотирьох основних напрямках. Результами будуть дії, такі як поворот праворуч чи ліворуч.

Узагальнено алгоритм працює як показано у наступних кроках:

1. Вибір структури мережі, що відповідає особі;

2. Формування популяції особин, заповнення їх матриці ваг випадковими числами від мінус 1 до 1 ;

3. Встановлення функції фітнесу (відповідності), це така функція, яка дозволяє розрахувати відповідність кожного індивіда;

4. Проведення ігрової сесії, та обчислення функції відповідності кожної особини на базі отриманих з цієї сесії результатів;

5. Вибір декількох найкращих (найвідповідніших) особин серед популяції та створення наступного покоління з обраних особин, використовуючи методи обміну генами та мутації . 
Алгоритм використовує відібраних особин (батьків), щоб створити нове потомство, яке є кращим за попереднє, як наслідок, наступне покоління виходить вже більш пристосованим до оточення;

6. Перехід до кроку 4 та повторення, поки умови зупинки не будуть виконані, а саме, гра не буде завершеною.

Плюси такого методу: проста для розуміння концепція. Після того, як модель навчена, прогнозування наступного ходу відбувається швидко.

Мінуси: необхідний результат може досягатись протягом тривалого часу, оскільки мутації випадкові. Ефективність моделі залежить від входів, доступних для моделі. Якщо вхідні дані лише описують, чи $є$ перешкоди в безпосередній близькості до змії, то остання не бачить повної картини і схильна потрапляти в пастку всередині власного хвоста.

\section{Навчання з підкріпленням}

Навчання з підкріпленням- це швидко зростаюча та захоплююче галузь ШІ. В цілому навчання 3 підкріпленням включає агента, середовище, набір дій, які може виконати агент, і функцію винагороди, яка заохочує агента за хороші дії або карає за погані. Поки агент досліджує навколишнє середовище, він оновлює свої параметри, щоб максимізувати власну очікувану винагороду. У випадку зі змією агентом, очевидно, $є$ змія. Середовище - це поле гри (з багатьма можливими станами цього середовища, залежно від того, де розташовані їжа та змія). Доступні дії - повернути ліворуч, повернути праворуч і продовжувати рухатися прямо.

Подібно до методу без машинного навчання, кожен стан гри пов'язаний із винагородою, яка може бути позитивною чи негативною, так алгоритм повинен зрозуміти, які дії можуть максимізувати винагороду, а яких слід уникати.

Власне алгоритм працює наступним чином:

1. На початку гри мережа ініціалізується з випадковими значеннями.

2. Модель аналізує поточний стан (навколишнє середовище) ;

3. Агент виконує дію на основі результату нейронної мережі. Також є ймовірність що агент виконає випадкову дію, а не на основі свого «мозку». Це реалізовано для того, щоб агент міг дослідити якомога більше ігрового поля та різних станів на ранньому етапі навчання.

4. Після виконання обраної дії, модель збирає дані про новий стан. Під час цієї фази система також обчислює кортеж, утворений старим станом, дією, винагородою та новим станом, і зберігає ії в пам'яті;

5. Щоразу, коли змія вмирає, вона вчиться, відбираючи випадкові кортежі з пам'яті, що дає агенту можливість вчитися на своїх минулих діях.

Плюси: Навчання з підкріпленням доволі універсальне, може застосовуватися і до багатьох інших завдань, не вимагає нагляду, окрім налаштування середовища та системи винагород. Результатів навчання такого алгоритму не доводиться чекати так довго, як з генетичними алгоритмами, адже він не мутує випадковим чином.

Мінуси: необхідно задати базовий перелік можливих дій агента. Так само, як у випадку генетичних алгоритмів, ефективність моделі залежить від того, які входи доступні для мережі, і чим цих входів більше тим більше параметрів моделі, що призводить до збільшення часу навчання.

\section{Практична частина}

Для тестування та оцінки даних методів навчання ігрових агентів було обрано засоби мови Руthon, оскільки ця мова вважається однією з найкращих для використання у сфері машинного навчання. Найбільшими перевагами у використанні Python можна виділити велику кількість бібліотек та фреймворків (таких як Numpy, TensorFlow, SciKit-Learn), які спрощують написання коду і час на його розробку. Ще вагомим плюсом $є$ гнучкість цієї мови, розробник може використовувати зручні для нього підходи, об'єктно орієнтоване програмування, або скрипти.

У роботі планується протестувати кожен з наведених методів на практиці у ігровому середовищі, яким було обрано гру Snake. Ідея полягає у тому, щоб з'ясувати, який з агентів, керований цими алгоритмами, найкраще пристосується до обраного ігрового середовища. Для цього планується провести ряд експериментів, які відбуватимуться у два етапи :

1. Для кожного 3 реалізованих агентів будуть проводитись тести у грі. Ми будемо по черзі запускати на ігрове поле агентів, тренувати їх та звертати увагу на: тривалість навчання агента, середню та максимальну кількість очок, які йому вдасться здобути.

2. Усі агенти одночасно будуть поміщені на ігрове поле, де будуть змагатись за спільний ресурс їжу. Таким чином ми створимо конкуренцію для цих агентів і побачимо, який з алгоритмів виявиться найбільш конкурентоспроможним для реальних гравців. 
Для прикладу наведено тестування одного з алгоритмів, а саме алгоритму навчання з підкріпленням.

\section{Перша стадія - навчання.}

Потрапляючи у невідоме для себе ігрове середовище (у нашому випадку - гру Snake,), агент, маючи лише елементи керування, не розуміє цілі гри та їі правил. На цьому етапі він просто рухається по полю збираючи якомога більше інформації про те, які дії позитивно впливають на його винагороду, а які навпаки, зменшують іiі. На рисунку 1.1 ми бачимо, як агент, з часом здобуває досвід та починає віддавати перевагу збиранню їжі. А на рисунку 1.2 - графік його навчання, 3 якого видно, що у середньому, за 300 проведених ігрових сесій агент у середньому навчився здобувати 32 бали, а його найкращі результати перевищували 50.
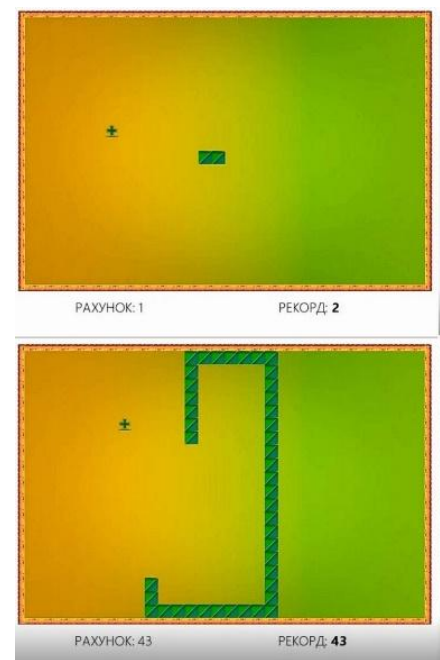

Рисунок 1.1 - Агент, керовний алгоритмом навчання з підкріпленням

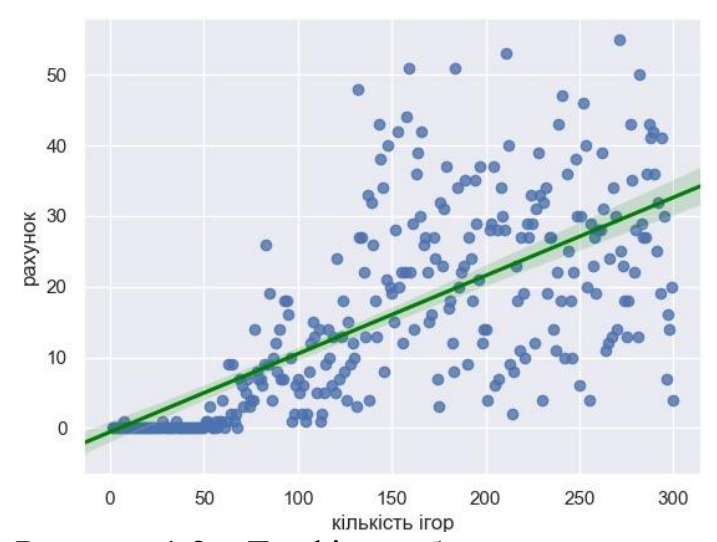

Рисунок 1.2 - Графік здобуття очок агентом під час навчання

Загалом, такі експерименти буде проведено для кожного з чотирьох алгоритмів. Щодо другої стадії, як уже згадувалось - на ігрове поле буде запущено одразу усі чотири змійки, де вони будуть конкурувати між собою.

\section{Висновок}

У даній роботі було обговорено основні завдання та обмеження розробки ігрового штучного інтелекту. Наведено основні методи, які використовуються у вирішенні завдань даної галузі. Кожен 3 вище згаданих методів було описано включно з їх варіаціями та алгоритмами. У результаті аналізу було відокремлено позитивні та негативні моменти у використанні цих алгоритмів.

У підсумку, можна сказати, що кожен з викладених методів заслуговує уваги. Адже є велика кількість обставин, які можуть обумовити використання саме такого алгоритму: розмір проектів, кількість даних, які повинен враховувати агент і вимоги до контакту з гравцями. Наприклад, немає необхідності у створенні «мозку» у випадку з простими об'єктами, які мають обмежений визначений функціонал, достатньо закодувати необхідну поведінку.

\section{References.}

1. Russell S. J. Artificial Intelligence: A Modern Approach / S. J. Russell, P. Norvig., 2019.

2. Togelius J. Playing Smart / Julian Togelius., 2019. - (Playful Thinking).

3. Lanham M. Hands-On Deep Learning for Games / Micheal Lanham., 2018.

4. Insa-Cabrera J. Comparing Humans and AI Agents / J. Insa-Cabrera, D. L. Dowe, V. M. Hernández-Lloreda // Artificial General Intelligence / J. Insa-Cabrera, D. L. Dowe, V. M. Hernández-Lloreda. - London: Springer, 2011. - C. 122-132.

5. Буковшин В. Интеллектуальные системы в компьютерных играх. Перспективы развития искусственного интеллекта в игровой индустрии / В. Буковшин, С. Воскобойников. // Современные материалы, техника и технологии. - 2017. - С. 2132.

6. Spronck P. Difficulty scaling of game AI / P. Spronck, I. Sprinkhuizen-Kuyper, E. Postma. // Universiteit Maastricht.

7. Мероник Т. Ігровий штучний інтелект-підходи до побудови : дис. техн. наук : 121 / Мероник Тетяна - Київ, 2020. - 42 с.

8. Safadi F. Artificial Intelligence in Video Games: Towards a Unified Framework [Електронний ресурс] / F. Safadi, R. Fonteneau, D. Ernst // International Journal of Computer Games Technology. - 2015. - Режим доступу до ресурсу: https://www.hindawi.com/journals/ijcgt/2015/271296/. 